\title{
ANALISIS YURIDIS DINAMIKA TINDAK PIDANA \\ DALAM PERSPEKTIF PERTANGGUNGJAWABAN KORPORASI
}

\author{
Jeane N. Saly ${ }^{*}$ \\ jeaneneltje@gmail.com
}

Fakultas Hukum Universitas Nasional Jakarta

\section{Abstract}

The impact of globalization has not only resulted in growth of increasingly thin state border, but also growth of legal events that are not only private, but also be public, as a criminal offense, which requires accountability as a result of the activities of large companies (corporate) in their activities, to the detriment public (public). The problem is how the development of corporate criminal offense settings and is responsible under the law in Indonesia, and other countries. The conclusion is that the offense and the responsibility of corporations in Indonesia are not regulated in the Criminal Justice Act (Criminal Code), but scattered in various legislation. The next development, both in criminal law and administrative law that have criminal sanctions have largely been set up of corporate as subjects of criminal law. In fact, in the General Explanation of the first book manuscript draft Law Code of Criminal Law (Draft-Criminal Code) 1999-2000 recognized. In other countries, criminal offense of corporate and its accountability is set up, especially the countries adherents of the common law system, are like the UK, the USA, and Canada, which started in the industrial revolution 1842. The district court in its decision to apply through penalties for the corporate fails to perform obligations under the legislation.

\section{Kata Kunci: Dinamika Tindak Pidana dan Pertanggungjawaban korporasi}

\section{Pendahuluan}

Para ahli hukum antara lain Mochtar Kusumaatmadja, ${ }^{1}$ mengatakan bahwa apabila hukum berfungsi dalam pembangunan, maka pembangunan tersebut akan berlangsung secara tertib. Dengan demikian dapat dikatakan bahwa keberhasilan pembangunan dapat terwujud secara tertib dan teratur apabila hukum dapat memenuhi kepentingan yang dibutuhkan dalam pembangunan.

Hal itu disebabkan karena di dalam pembangunan terjadi dilema, disamping pembaharuan dan perombakan berbagai aspek yang menunjang terselenggaranya keinginan pemerintah guna mencapai masyarakat yang sejahtera, juga perlu merespons perkembangan global yang diikuti dengan peningkatan teknologi.

Dampak dari berkembangnya globalisasi tidak hanya berakibat tipisnya batas wilayah negara, tetapi juga berkembangnya peristiwa hukum yang tadinya hanya bersifat privat, berkembang menjadi bersifat publik sebagai akibat kegiatan perusahaan-perusahaan bermodal

\footnotetext{
${ }^{*}$ Guru Besar Fakultas Hukum Universitas Nasional Jakarta

${ }^{1}$ Mochtar Kusumaatmadja, Fungsi Hukum Dalam Pembangunan, Bandung: Bina Cipta, 1979, hal. 7
}

besar dalam melakukan aktivitasnya merugikan masyarakat (public). Dalam kaitan ini, maka hukum hendaknya melaksanakan fungsinya, yaitu menampung kepentingan masyarakat.

Perusahaan-perusahaan besar tersebut biasanya berbadan hukum yang disebut korporasi, ${ }^{2}$ yang diharapkan dapat menunjang peningkatan ekonomi nasional, berusaha atas dasar prinsip ekonomi yakni mencari keuntungan sebesar-besarnya, dan mempunyai kewajiban untuk mematuhi peraturan hukum di bidang ekonomi yang digunakan pemerintah guna mewujudkan kesejahteraan masyarakat dan keadilan sosial.

Disamping dampak yang menguntungkan tersebut, dapat terjadi dampak negatif yang berakibat kerugian bagi masyarakat, khususnya konsumen, Oleh karena itu perlindungan hukum bagi masyarakat melalui pengaturan hukum terhadap kegiatan korporasi itu dibutuhkan. Pengaturannya terkait dengan bagaimana mengkonstruksikan kejahatan yang dila-

\footnotetext{
${ }^{2}$ Utrecht, Pengantar Ilmu Hukum, Badan yang menurut hukum berwenang menjadi pendukung hak atau setiap pendukung hak yang tidak berjiwa, Jogyakarta: RadjaGrafindo, 1990, Cetakan ke 7. hal. 21
} 
kukan korporasi dalam kegiatan usahanya.

Ajaran yang banyak dianut terkait dengan tindak pidana dan pertanggungjawaban korporasi saat ini dalam perkembangannya, memisahkan antara perbuatannya yang melawan hukum (menurut hukum pidana) dengan pertanggungjawabannya menurut hukum pidana. Dalam perkembangan pendididkan ilmu hukum pidana di Indonesia terdapat dua aliran ajaran. Pertama, monistis berpendapat bahwa pertanggungjawaban pidana (sebagai unsur subyektif-terdapat pada pelaku) melekat pada perbuatan melawan hukumnya (unsur obyektif), sedangkan pendapat kedua, dualistis memisahkannya.

Dapat dikatakan bahwa apabila Indonesia menerima ajaran kedua, maka korporasi dapat bertanggungjawab pidana, atas perbuatan melawan hukum organ korporasi. Perbuatan melawan hukum ini dilakukan oleh suatu korporasi yang sekarang telah dimungkinkan.

Kalangan ahli hukum mempertanyakan tentang bagaimana mempertimbangkan tentang pertanggungjawabannya? Apakah korporasi dalam tindakannya terdapat unsur kesalahan (baik kesengajaan atau dolus ataupun kelalaian atau culpa)? Apabila pengurus, maka kesalahan ini dikaitkan dengan celaan (verwijtbaarheid; blameworthiness) dan karena itu berhubungan dengan mentalitas atau psyche pelaku, sedangkan bagaimana dengan pelaku yang tidak memiliki psyche karena bukan manusia, yaitu korporasi.

Dalam praktek tindak pidana korporasi sering terjadi dalam kegiatan usaha yang menimbulkan kerugian masyarakat. Oleh sebab itu diperlukan aturan untuk menjadi patokan dalam pelaksanaan usahanya tersebut. Sayangnya aturan dalam KUHP masih menganut pola KUHP Belanda yang berasal dari pola KUHP tahun 1886 yang tidak mengatur tentang kejahatan korporasi sebagai tindak pidana.

Aturan yang ada terpencar dalam berbagai produk hukum, berakibat menimbulkan penafsiran yang berbeda, antara lain dalam UU RI No. 5 tahun 1984 tentang Perindustrian, UU RI No. 32 tahun 2009 tentang Perlindungan dan Pengelolaan, UU RI No. 8 tahun 1995 tentang Pasar Modal. Isinya korporasi sebagai subyek tindak pidana namun dengan berbagai variasi, tidak mengatur tentang pertanggungjawaban pidana.
Hal itu bisa dilihat dalam kasus-kasus White Collar Crime (wcc) dan Corporate Crime.

\section{Permasalahan}

1. Bagaimana perkembangan pengaturan tindak pidana korporasi dan pertanggungjabannya menurut hukum di Indonesia?

2. Bagaimana pengaturan kejahatan korporasi dan pertanggungjawabannya di negara lain?

\section{Tujuan Penulisan}

1. Untuk Mengetahui Perkembangan pengaturan tindak pidana korporasi dan pertanggungjawabannya menurut hukum di Indonesia.

2. Untuk mengetahui perkembangan kejahatan korporasi dan pertanggungjawabannya di Indonesia.

\section{Dinamika Pengaturan Korporasi Dalam KUHP}

Berkembangnya korporasi (rechtpersoon) dari subyek hukum dalam bidang privat ke subyek hukum dalam bidang publik berdampak terhadap kegiatan korporasi yang merugikan masyarakat harus dipertanggungjawabkan. Korporasi merupakan badan hukum yang diberikan oleh hukum. Caranya adalah dengan menunjuk adanya suatu badan yang diberi status sebagai subjek hukum, di samping subjek hukum yang berwujud manusia alamiah (natuurlijk persoon).

Korporasi sebagai subyek hukum, menjalankan kegiatannya sesuai dengan prinsip ekonomi yakni mencari keuntungan sebesarbesarnya, dan mempunyai kewajiban untuk mematuhi peraturan hukum di bidang ekonomi yang digunakan pemerintah guna mewujudkan kesejahteraan masyarakat dan keadilan sosial.

Pertanggungjawaban kejahatan korporasi di Indonesia tidak diatur dalam Kitab UndangUndang Hukum Pidana (KUHP), tetapi terpencar dalam berbagai undang-undang.

KUHP yang berlaku saat itu (di Hindia Belanda) adalah KUHP 1886 adalah Wetboek van Strafrecht voor Nederlandsch-Indie, berla$\mathrm{ku}$ pula di negeri Belanda sebagai pengganti Code Penal yang berlaku sebelumnya. Menurut pembentuk saat itu bahwa sebaiknya untuk Hindia-Belanda diberlakukan satu KUHP saja, 
yang berlaku bersama untuk golongan Eropa dan golongan Indonesia (Bumiputera) dan Timur-Asing. ${ }^{3}$

Konsep yang dipakai adalah KUHP 1886 yang berlaku di Belanda sebagai pengganti Code Penal, ${ }^{4}$ yang berlaku sebelumnya. Berlakunya KUHP Belanda bagi Hindia-Belanda, menimbulkan berbagai pandangan, yaitu secara umum ada yang menentang dan ada yang mendukung.

Pendapat yang menentang kesatuan (unifikasi) berpandangan bahwa aturan yang berasal dari Belanda tersebut belum tentu berfungsi bagi masyarakat Bumiputera yang kehidupannya sederhana. bahwa kesederhanaan masyarakat Bumiputera belum memungkinkan mereka dapat menyesuaikan diri pada asas-asas hukum yang berlaku untuk golongan Eropa di Hindia Belanda. Hal itu dapat diterima karena kebutuhan masyarakat Belanda tentunya tidak sama dengan kebutuhan masyarakat Bumiputera.

Hukum yang satu tersebut berlaku bagi seluruh jajahan, yang masyarakatnya bersifat heterogen, tidak akan efektif karena tidak memenuhi kebutuhan masyarakat di tempat hukum itu berlaku.

Sebaliknya mereka yang mendukung kesatuan berpendapat, bahwa dalam perkembangan kekuasaan administrasi Belanda di Hindia-Belanda, KUHP untuk golongan Bumiputera dan Timur-Asing (mulai berlaku 1873), dalam praktek peradilan, telah disamakan (dengan beberapa perkecualian) dengan KUHP untuk golongan Eropa (mulai berlaku 1886). ${ }^{5}$ Bahwa dalam hal-hal tertentu diatur pengecualiannya.

Hal itu berakibat sejak tahun 1873 "hu-

\footnotetext{
${ }^{3}$ Mardjono Reksodiputro, Tindak Pidana Korporasi Dan Pertanggungjawabannya, Perubahan Wajah Pelaku Kejahatan di Indonesia, http://mahupiki.com/ demo/images/Artikel/Jogya23-27 Februari 2014/ Tindak_Pidana_Korporasi, hal.2

${ }^{4}$ Ibid, hal. 3

5 Mardjono Reksodiputro, Op.,Cit, hal. 4. Lihat Geschiedenis van het Wetboek van Strafreht voor Nede rlandsch Indie, Amsterdam:J.H.de Bussy,1918 ; G.A.van Hamel,1927,Inleiding tot de studie van het Nederlandsche Strafrecht, Haalem: De Erven F. Bohn; dan buku Menteri Kehakiman Belanda H. J. Smidt, 1878, Geschiedenis van het Wetboek van Strafrecht (dipergunakan tahun 1880 oleh Menteri Kehakiman Moderman di Parlemen Belanda). [lihat selanjutnya Catatan A di akhir makalah ini]
}

kum pidana bumiputera" atau "hukum pidana adat" telah dihapuskan oleh Pemerintah Hindia Belanda, maka antara tahun 1909-1913 disusunlah rancangan KUHP yang berlaku untuk semua golongan, dengan mempergunakan sebagai contoh KUHP Belanda 1886, dan kemudian diajukan kepada pemerintah di Belanda pada tahun 1914.

Rancangan ini, dengan beberapa perubahan, diumumkan di Hindia-Belanda pada bulan Desember 1915, dan kemudian pada tanggal 31 Desember 1917, dinyatakan akan berlaku mulai tanggal 1 Januari 1918 di HindiaBelanda. Inilah riwayat singkat KUHP yang sekarang berlaku di wilayah Republik Indonesia.

Dalam rancangan KUHP Hindia-Belanda 1918 tersebut ketentuan Pasal 59 tidak diubah dalam sejarah pembentukannya. Rumusannya tepat sama dengan pasal 51 lama KUHP Belanda 1886. Pasal 59 dan pasal 51 ini memuat suatu alasan penghapus pidana untuk pengurus yang tidak terlibat dalam terjadinya tindak pidana. Sejak semula pasaI ini telah mengundang pertanyaan: "apakah suatu kesatuan-orang atau korporasi (seperti pribadi hukum atau "zakelijk lichaam", perkumpulan orang atau "collectieve persoon", serta badan hukum dan komunitas) dapat merupakan subyek hukum pidana. Pada dasarnya tidak mungkin dalam hukum pidana umum suatu korporasi menjadi subyek dari suatu tindak pidana. Yang dapat meniadi subyek hukum pidana hanyalah manusia.

Permasalahan ini dikemukakan dalam buku pelajaran hukum pidana dalam tahun 1920-an. ${ }^{6}$ Karena hubungan yang ada antara KUHP Hindia-Belanda dengan KUHP Belanda, maka di Indonesia dianut pula pendapat yang sama.

\section{Analisis Pertanggungjawaban \\ Korporasi Perspektif Ketentuan}

Pertanggungjawaban pidana korporasi

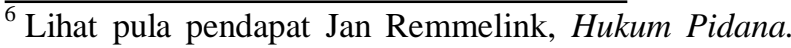
Komentar atas pasal-pasal terpenting KUHP Belanda dan padanannya dalam KUHP Indonesia, Jakarta: Gramedia, 2003, hal. 97-99, yang menyatakan bahwa dari tinjauan sejarah, maka KUHP Belanda pada awalnya menolak pertanggungjawaban korporasi berdasarkan ungkapan delinquere on potest -korporasi tidak mungkin melakukan tindak pidana. [lihat selanjutnya pula Catatan Bdi akhir makalah ini
} 
dianut oleh negara-negara yang menganut sistem hukum common law, seperti Inggris, dan Amerika Serikat serta Kanada, yang diawali sebagai akibat revolusi industri pada tahun 1842. Pengadilan negeri menerapkan dalam putusannya melalui denda karena korporasi lalai melaksanakan kewajibannya dalam peraturan perundang-undangan.

Praktek pertanggungjawaban korporasi kurang diperhatikan didasari anggapan bahwa korporasi merupakan subyek hukum fiksi, dan menurut paham ultra vires (bersalah karena bertindak melewati kewenangan) kesalahan yang dapat dihukum apabila melanggar Anggaran Dasar Korporasi, serta terdapat hambatan-hambatan lain seperti kurangnya mens rea (niat untuk melakukan kejahatan) serta siapa yang harus hadir dalam persidangan secara pribadi. $^{7}$

Mens area, pada dasarnya dimiliki oleh "manusia" yang melakukan perbuatan. Sebab elemen umum mental (general mental element) yang melekat pada mens rea, antara lain: maksud (intention), sembrono (recklesness), motif jahat (malice), penuh sadar (wilful), mengetahui (knowledge), dan lalai (negligence). Semua elemen itu, hanya melekat secara inheren pada diri manusia. Hal ini semua dapat menjadi hambatan untuk menghukum korporasi dengan sanksi yang setimpal.

Ketentuan dalam Bab V, Pasal 59 KUHP, yaitu bahwa: "Dalam hal-hal dimana karena pelanggaran ditentukan pidana terhadap pengurus, anggota-anggota badan pengurus atau komisaris, maka pengurus, anggota badan pengurus atau komisaris yang ternyata tidak ikut campur melakukan pelanggaran tidak dipidana".

Perkembangan selanjutnya, baik dalam perundang-undangan pidana maupun perundang-undangan administrasi yang bersanksi pidana sebagian besar telah mengatur korporasi sebagai subyek hukum pidana. Bahkan, dalam Penjelasan Umum Buku I Naskah Rancangan Undang-Undang Kitab Undang-Undang $\mathrm{Hu}-$ kum Pidana (RUU-KUHP) 1999-2000 dinyatakan: "Mengingat kemajuan yang terjadi dalam bidang ekonomi dan perdagangan, maka subyek hukum pidana tidak dapat dibatasi ha-

\footnotetext{
${ }^{7}$ Alvi Syahrin, Pertanggungjawaban Pidana Korporasi. http://alviprofdr.blogspot.com/ 2013/02 /pertanggungjawabanpidana-korporasi-oleh.html, hal. 1
}

nya pada manusia alamiah (natural person), tetapi juga mencakup manusia hukum (jurisical person) yang lazim disebut korporasi, karena tindak pidana tertentu dapat pula dilakukan oleh korporasi.

Selanjutnya prinsip pertanggungjawaban korporasi banyak diadopsi dalam peraturan perundang-undangan, seperti: UU RI No. 5 tahun 1984 tentang Perindustrian, UU RI No. 8 tahun 1995 tentang Pasar Modal, UU RI No. 5 tahun 1997 tentang Psikotropika, UU RI No. 22 tahun 1997 tentang Narkotika, UU RI No. 32 tahun 2009 tentang Perlindungan Pengelolaan, UU RI No. 5 tahun 1999 tentang Larangan Praktek Monopoli dan Persaingan Usaha Tidak Sehat, UU RI No. 8 tahun 1999 tentang Perlindungan Konsumen, dan UU RI No. 20 tahun 2001 tentang Pemberantasan Tindak Pidana Korupsi. Juga dikenal dalam dua undangundang yang sudah direvisi dan dibatalkan oleh Mahkamah Konstitusi, yakni UU RI No. 22 tahun 2001 tentang Minyak dan Gas Bumi dan UU RI No. 20 tahun 2002 tentang Ketenagalistrikan. Namun pengaturan dalam berbagai undang-undang yang terpencar tersebut terkait dengan pengertian pertanggungjawaban korporasi, belum ada pengaturan tentang pola pertanggungjawaban korporasi secara konsisten.

Menurut Barda Nawawi Arief, perumusan pertanggungjawaban pidana korporasi dalam perundang-undangan selama ini (undangundang pidana khusus) terlihat hal-hal sebagai berikut:

1. banyak yang memasukkan "korporasi" sebagai subyek tindak pidana, namun dengan berbagai variasi istilah;

2. ada korporasi yang dijadikan subyek tindak pidana, tetapi undang-undang yang bersangkutan tidak membuat ketentuan pidana atau "pertanggungjawaban pidana" untuk korporasi;

3. dalam hal Undang-Undang membuat pertanggungjawaban korporasi, belum ada pola aturan pemidanaan korporasi yang seragam dan konsisten, antara lain terlihat halhal sebagai berikut:

- ada yang merumuskan dan ada yang tidak merumuskan "kapan korporasi melakukan tindak pidana dan kapan dapat dipertanggungjawabkan";

- ada yang merumuskan dan ada yang tidak merumuskan, "siapa yang dapat di- 
pertanggungjawabkan";

- jenis sanksi:

Korporasi sebagai subyek hukum, berarti korporasi sebagai bentuk badan usaha harus mempertanggungjawabkan sendiri semua perbuatannya. Di samping itu, masih dimungkinkan pula pertanggungjawabannya.

Pertanggungjawaban pengurus menimbulkan pemikiran para ahli hukum berakibat timbulnya tiga ajaran. Ajaran pertama mengatakan bahwa pertanggungjawaban korporasi berada pada pengurus, dan korporasi bukan subyek hukum. Ajaran kedua mengatakan bahwa "korporasi dapat diakui sebagai pelaku (dader), tetapi pertanggungjawaban pidananya (penuntutan dan pemidanaan) berada pada pengurus", pandangan-pandangan. Ajaran ketiga menyatakan bahwa korporasi dapat menjadi pelaku tindak pidana dan sekaligus bertanggungjawab atas tindakan tersebut.

Ajaran pertama bersandar pada pandangan bahwa pertanggungjawaban korporasi berada pada pengurus yang berfungsi sebagai zorgplicht (mengelola) Sesuai ketentuan dalam Pasal 59 KUHP tersebut, maka pandangan hukum dalam pendidikan, maupun dalam praktek di Indonesia, adalah bahwa beban "tugas mengurus" (zorgplicht) suatu korporasi berada pada pengurusnya. Korporasi bukan subyek tindak pidana. Apabila pengurus tidak memenuhi kewajiban korporasi, maka mereka yang bertanggungjawab menurut hukum pidana. Di dalam praktek, ajaran pertama ini masih menimbulkan permasalahan.

Para ahli hukum mempertanyakan tentang bagaimana kalau ketentuan pidana yang bersangkutan memang telah mernberikan kewajiban kepada seseorang pemilik perusahaan atau pengusaha, sedangkan pemilik atau pengusahanya adalah suatu korporasi, akan tetapi ketentuan pidana tersebut tidak menyatakan bahwa penguruslah yang harus bertanggung jawab. Pengurus yang harus dianggap sebagai pelaku tindak pidana itu.

Ajaran kedua yang menyatakan bahwa "korporasi dapat diakui sebagai pelaku (dader), tetapi pertanggungjawaban pidananya (penuntutan dan pemidanaan) berada pada pengurus", Oleh karena itu pasal 59 KUHP kita (Pasal 51 lama KUHP Belanda) harus ditafsirkan menurut ajaran kedua ini, yaitu bahwa korporasi dapat melakukan tindak pidana, hanya saja pertanggungjawaban pidananya dibebankan kepada pengurus. ${ }^{8}$

Pengurus dapat dihapus pidananya apabila pengurus yang dapat membuktikan bahwa dirinya tidak terlibat, sedangkan pengurus yang lain dapat dipidana. Namun belum tentu pengurus ini adalah pelaku menurut hukum pidana. Apabila ketentuan pidana yang bersangkutan memberikan kewajiban kepada pengusaha yang berupa korporasi, maka korporasi inilah yang menurut hukum pidana harus dianggap sebagai pelaku. ${ }^{9}$ Korporasi adalah perusahaan yang memperoleh status sebagai badan hukum oleh undang-undang.

Penafsiran ini menghendaki agar ada perubahan pandangan dalam dunia pendidikan dan praktek di Indonesia yang bersandar pada orientasi bahwa KUHP kita hanya mengenal manusia sebagai subyek hukum pidana, menjadi bukan hanya manusia saja tetapi korporasi atau badan hukum (persoonlijkerecht) juga sebagai subyek hukum yang dapat dibebani tanggung jawab dalam melakukan suatu akibat dari perbuatannya.

Ketentuan tentang korporasi dapat melakukan kejahatan dan akibatnya bertanggung jawab terhadap kejahatannya walaupun belum dituangkan dalam KUHP ternyata dalam praktek dibutuhkan, oleh sebab itu diatur di luar KUHP, yang menganut ajaran ketiga, yaitu bahwa korporasi dapat dipertanggungjawabkan.

Sesungguhnya negara asal yaitu Belanda, ketentuan dalam KUHP terkait dengan kejahatan korporasi sudah diatur sejak tahun 1950. Selanjutnya pada tahun 1976 ketentuan Pasal 51 tersebut diubah oleh Belanda sehingga ketentuan tersebut lebih tegas dengan nor-

${ }^{8}$ Op.,Cit Masdjono Reksodiputro, Tindak Pidana Korporasi dan Pertanggungjawabannya, Pidato Dies Natalis PTIK, Jakarta, 2014.

${ }^{9}$ Menurut Remelink (hal.100) perubahan dengan maksud untuk memungkinkan Korporasi dipandang sebagai pelaku dimulai pada hukum pidana fiskal, karena adanya "kewajiban yang dibebankan oleh hukum fiskal kepada pemilik,penyewa atau yang menyewakan ... yang sering kali berbentuk korporasi”. Uraian perubahan ini juga dijabarkan dalam Schaffmeister, Keijzer, Sutorius, 1995, Hukum Pidana, Editor Penerjemahan J.E.Sahetapy, Konsorsium Ilmu Hukum, Yogyakarta:Liberty, hal.272-283 dan 423434. [lihat selanjutnya Catatan $\mathrm{C}$ pada akhir makalah ini]. 
ma "tindak pidana dapat dilakukan oleh manusia (natuurlijke personen) dan badan hukum (rechtspersonen)". Ketentuan tersebut dituangkan dalam Undang-Undang Delik Ekonomi (Wet op de Economische Delicten), yang kemudian direspons oleh Indonesia pada tahun 1955 dalam Undang-Undang RI Nomor 7 Drt tahun 1955, Tentang Tindak Pidana Ekonomi.

Menurut para ahli hukum Indonesia, antara lain Mardjono Reksodiputro, ${ }^{10}$ Apabila nanti Rancangan KUHP Nasional diterima menjadi peraturan perundang-undangan Indonesia, dan memuat ketentuan bahwa korporasi dapat merupakan subyek hukum pidana, maka ajaran ketiga di atas telah masuk pula dalam hukum pidana umum Indonesia. ${ }^{11}$

Dengan (akan) diterimanya korporasi sebagai subyek hukum pidana, maka hal ini berarti telah terjadi perluasan dari pengertian siapa yang merupakan pelaku tindak pidana (dader).

Terkait dengan hal itu, asas utama dalam pertanggungjawaban pidana adalah harus adanya kesalahan (schuld) pada pelaku. Terkait dengan pertanggungjawaban korporasi menjadi masalah adalah mengkonstruksikan kesalahan dari suatu korporasi tersebut.

Ajaran yang banyak dianut sekarang ini memisahkan antara perbuatannya yang melawan hukum (menurut hukum pidana) dengan pertanggungjawabannya menurut hukum pidana. Dalam perkembangan pendidikan ilmu hukum pidana di Indonesia terdapat dua aliran ajaran. Pertama (monistis), berpendapat bahwa pertanggungjawaban pidana (sebagai unsur subyektif-terdapat pada pelaku) melekat pada perbuatan melawan hukumnya (unsur obyektif), sedangkan pendapat kedua (dualistis) memisahkannya.

\footnotetext{
${ }^{10}$ Mardjono Reksodiputro, ibid, hal. 5

11 Agustinus Pohan,1988, "Korporasi sebagai Subyek dalam Hukum Pidana" (Penataran di FH Universitas Lampung); Mardjono Reksodiputro, 1989, "Pertanggungjawaban Pidana Korporasi dalam Tindak Pidana Korporasi”" (Seminar Nasional di FH Universitas Diponegoro); Muladi dan Dwidja Priyatno, 1991, Pertanggungjawaban Korporasi dalam Hukum Pidana, Sekolah Tinggi Hukum, Bandung; Sutan Remy Sjahdeini, 2006, Pertanggungjawaban Pidana Korporasi, Grafiti Pers; Eddy O.S. Hiariej (Editor), 2006, Bunga Rampai Hukum Pidana Khusus, Pena Pundi Aksara; Yusuf Shofie, 2011, Tanggung Jawab Pidana Korporasi dalam Hukum Perlindungan Konsumen Di Indonesia, Citra Aditya Bakti.
}

Terkait dengan konstruksi hukumnya bahwa perbuatan pengurus (atau orang lain) dapat dinyatakan sebagai perbuatan korporasi yang melawan hukum (menurut hukum pidana, dan konstruksi hukumnya bahwa pelaku korporasi dapat dinyatakan mempunyai kesalahan dan karena itu dipertanggungjawabkan menurut hukum pidana.

Lebih sulit apabila dipahami bahwa hukum pidana kita mempunyai asas yang sangat mendasar yaitu, bahwa: "tidak dapat diberikan pidana, apabila tidak ada kesalahan (dalam arti celaan)".

Sesungguhnya dalam praktek Indonesia sudah menerapkan tindak pidana korporasi, dan pertanggungjawabannya sejak tahun 1955

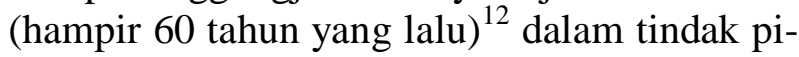
dana ekonomi.

Sesungguhnya wajah pelaku kejahatan di Indonesia megalami perubahan yang berarti sejak tahun 1955, ketika undang-undang tindak pidana ekonomi dinyatakan berlaku di Indonesia. atau dengan perkataan lain dalam pembangunan selama masa Orde Lama 19551967) dan Orde Baru (1967-1998), dimana korporasi memainkan peranan penting dalam kualitas kejahatan yang terjadi di negara kita, termasuk saat ini dalam masa Era Reformasi yang sudah berjalan.

Saat ini, tindak pidana korporasi, merupakan kejahatan korporasi oleh kelas ekonomi tingkat atas, seperti yang biasa disebut "white collar criminality" (WCC). Istilah WCC tampil pada tahun 1939 di Amerika Serikat, yang diartikan sebagai : "suatu pelanggaran hukum pidana oleh seseorang dari kelas sosial-ekonomi atas, dalam pelaksanaan kegiatan jabatannya".

\footnotetext{
${ }^{12}$ Mardjono Reksodiputro, 2007, Kemajuan Pembangunan Ekonomi dan Kejahatan, Lembaga Kriminologi UI, hal.46-73 dan Mardjono Reksodiputro, 2007, Bunga Rampai Permasalahan dalam Sistem Peradilan Pidana, Lembaga Kriminologi UI. hal. 136-155. Mungkin masih ada beberapa kasus yang kurang terkenal, tetapi yang saya kenal adalah kasus PT Newmont Mina-hasa Raya, di mana Terdakwa-1 adalah Perseroan Terbatas dan Terdakwa-2 adalah Presiden Direkturnya. Sayang, JPU dan Pengadilan Tidak memberi pendapat hukum mengenai mengapa suatu korporasi dapat didakwa melakukan perbuatan tindak pidana.
} 
Keenan wicaksono ${ }^{13}$ mengatakan bahwa WCC ditujukan kepada pelaku manusia (natuurlijk persoon), yang melakukan perbuatan tercela dan karena itu harus dimintakan pertanggungjawaban pidana adalah perusahaan atau korporasi tempat manusia yang bersangkutan bekerja, yang ditambahkan dengan unsur violation of trust atau unsur "penyalahgunaan kepercayaan". Kepercayaan diterima dari masyarakat untuk melakukan kegiatannya (dalam bidang perekonomian) secara jujur dan beritikad baik, termasuk dalam etika bisnis yang baik. Perusahaan-perusahaan yang melakukan kegiatan yang merugikan masyarakat dianggap menyalahgunakan kepercayaan tersebut dan kegiatannya termasuk dalam pengertian WCC. Apalagi kejahatan atau tindak pidana korporasi tersebut menimbulkan keresahan luas dalam masyarakat, antara lain berupa kerugian besar, baik berupa kerugian yang dapat dihitung dengan uang, maupun kerugian yang tidak dapat dihitung, yaitu misalnya hilangnya kepercayaan masyarakat pada sistem perekonomian yang berlaku.

Dalam kenyataannya dapat saja terjadi penipuan terhadap masyarakat (defrauding the public), seperti: penentuan harga secara tidak wajar (fixing prices) dan berbohong tentang mutu atau khasiat barang (misrepresenting products).

Sedangkan kategori yang lain adalah membahayakan masyarakat (endangering the public), seperti dalam hal pencemaran.dan perusakan lingkungan atau membahayakan keselamatan dan kesehatan pekerja. Semua kegiatan ini harus berhubungan dengan kegiatan ekonomi (perekonomian) dan atau berkaitan dengan dunia bisnis. ${ }^{14}$

Tindak pidana korporasi hendaknya dilihat sebagai bagian Dari WCC, untuk membedakannya dari pelanggaran hukum pidana atau ketentuan pidana yang dilakukan oleh perusahaan atau usaha dagang yang berlingkup kegiatan ekonomi atau bisnis dengan skala kecil

13 Keenan Wicaksono, "White Collar Criminality (WCC) Dalam penentuan Pertanggungjawaban-nya". Hinn \& Hill, Jakarta, 2009, hal. 12

${ }^{14}$ Lihat misalnya Susanto, 1995, Kejahatan Korporasi, Badan Penerbit Universitas Diponegoro dan Yusuf Shofie, 2002, Pelaku Usaha, Konsumen dan Tindak Pidana Korporasi, Ghalia Indonesia. atau terbatas. ${ }^{15}$

Di negara-negara penganut Common Law System, seperti Amerika dan Inggris, masalah kesalahan dan pertanggungjawaban pidana korporasi dapat dipecahkan, ditunjang oleh pandangan bahwa meskipun korporasi tidak mungkin mempunyai kesalahan, akan tetapi pemidanaan korporasi hendaknya dimungkinkan. $^{16}$

Mardjono Reksodiputro dalam bahan presentasi pada Dies Natalis PTIK tahun 2014 mengemukakab tentang pandangan LaFave bahwa :"Contrary to the early common law view, it is now generally conceded that a corporation may be held criminally liable for conduct performed by an agent of the corporation acting In its behalf within the scope of his employment ....Under the better view, called the "superior agent" rule, corporate criminal liability for Other than strict-liability regulatory offenses is limited to situations in which the conduct is performed or participated in by the board of directors or a high managerial agent". 17

Pada dasarnya pemikiran ini datangnya dari para ahli hukum Anglo-Amerika (common law countries -CLC) dengan mempergunakan konsep "strict liability".

Konsep ini khusus dimaksudkan untuk menanggulangi tindak pidana yang melanggar kesejahteraan masyarakat (public welfare offenses). Dan umumnya pelanggaran-pelanggaran besar terhadap ketentuan-ketentuan tentang kesejahteraan masyarakat dilakukan oleh korporasi.

Kewajiban negara modern untuk secara lebih luas melindungi kesejahteraan masyarakatnya, menimbulkan berbagai pengaturan mengenai misalnya: bidang keselamatan dan kesehatan di tempat kerja dan tempat pemuki-

${ }^{15}$ Dalam perkuliahan saya membedakan antara WCC (Kejahatan Kerah-Putih) yang merupakan kejahatan individual yang dilakukan oleh manajemen atau organ korporasi, dengan Kejahatan Oleh Organisasi (KOO), yaitu Corporate Crime yang memerlukan corporate criminal liability-dan saya bedakan lagi dari Kejahatan Terorganisasi (KTO), yaitu Organized Crimeyang dilakukan oleh Mafia,Yakusa,Triad.

${ }^{16}$ Lihat Wayne R. LaFave\& Austin W. Scott, Jr, Criminal Law-Hornbook Series, 1972, West Publishing Co, hal. 218-236 (Laibility Without Fault: Strict Liability -Vicarious Liability -Enterprise Liability)

${ }^{17}$ Mardjono Reksodiputro, Tindak Pidana Korporasi, Jakarta, Dies Natalis PTIK Tahun 2014, hal. 1b. 
man, serta dalam pengolahan makanan dan obat-obatan. Meskipun pengaturan dapat disertai sanksi perdata ataupun sanksi administratif, namun terdapat kecenderungan kuat untuk mengaturnya pula melalui ketentuan-ketentuan (sanksi) pidana. Yang terakhir inilah yang sering dinamakan "administrative penal law" Atau "verwaltungsstraf-recht". Untuk bidang hukum pidana inilah, konsep "strict liability" umumnya dipergunakan.

Penggunaannya didasarkan pada : ".... usually given for strict-liability crimes is that in some areas of conduct it is difficult to obtain convictions if the prosecutions must prove fault...". 18 Penggunaannya adalah umumnya untuk tindak pidana dengan ancaman hukuman ringan atau dengan mempertimbangkan besarnya kerugian pada masyarakat (seriousness of harm to the public).

Terdapat perbedaan pendapat tentang apakah tindak pidana yang tidak mensyaratkan mens rea adalah konstitusional. Inti perbedaan pendapat berkisar pada perlu adanya sifat blameworthy (tercela) pada perbuatan yang dilarang tersebut, untuk dapat diancam pidana. ${ }^{19}$

Dalam hal sistem hukum kita tidak mengenal ajaran "strict liability" (tanggungjawab mutlak; absolute liability), dapat dipergunakan ajaran "fait materiel", Dalam kedua ajaran itu tidaklah penting adanya unsur kesalahan dalam perbuatan korporasi. Ajaran "fait materiel" dikenal di Indonesia melalui bahan pustaka hukum Belanda.Tidak demikianlah halnya dengan ajaran "strict liability", namun demikian konsep ini mulai diperkenalkan juga dalam tulisan-tulisan hukum Indonesia. ${ }^{20}$

Konsep "strict liability" ini dalam hukum Anglo-Amerika mengajarkan adanya pertanggungjawaban tanpa kesalahan (liability without fault) dan ditujukan kepada tindak pidana yang tidak membutuhkan "mens rea" (keadaan batiniah yang salah). Karena itu konsep ini hanya dipergunakan untuk tindak pidana

\footnotetext{
${ }^{18}$ Nico Keijzer, 2013, Criminal Liability of Corporations Under the Law of the Netherlands, tidak diterbitkan, dikirim dengan e-mail 15 Juni 2013sebagai teks makalah yang telah dipresentasikannya di Jakarta di muka forum Satgas REDD UKP4 pada tanggal 20 Mei 2013

19 Ineke Warsito, Tindakan kejahatan Korporasi dan Pertanggungjawabannya, Hill \& Co, Jakarta, 1898, hal. 11

${ }^{20}$ Ineke Warsito, Ibid, hal 12
}

ringan (regulatory offenses) yang hanya mengancamkan pidana denda, seperti pada kebanyakan "public welfare offenses".

\section{Kesimpulan}

1) Pertanggungjawaban kejahatan korporasi di Indonesia tidak diatur dalam KUHP, tetapi terpencar dalam berbagai undang-undang. KUHP yang berlaku saat itu (di Hindia Belanda) adalah KUHP 1886 yang adalah Wetboek van Strafrecht voor Nederlandsch-Indie, berlaku pula di negeri Belanda sebagai pengganti Code Penal yang berlaku sebelumnya. ${ }^{21}$ Menurut pembentuk saat itu bahwa sebaiknya untuk Hindia-Belanda diberlakukan satu KUHP saja, yang berlaku bersama untuk golongan Eropa dan golongan Indonesia (Bumiputera) dan Timur-Asing. ${ }^{22}$ Perkembangan selanjutnya, baik dalam perundang-undangan pidana maupun perundang-undangan administrasi yang bersanksi pidana sebagian besar telah mengatur korporasi sebagai subyek hukum pidana. Bahkan, dalam Penjelasan Umum Buku I Naskah Rancangan Undang-Undang Kitab Undang-Undang Hukum Pidana (RUU-KUHP) 1999-2000 dengan alasan kemajuan yang terjadi dalam bidang ekonomi dan perdagangan, Selanjutnya prinsip pertanggungjawaban korporasi banyak diadopsi dalam peraturan perundang-undangan, seperti: UU RI No. 5 tahun 1984 tentang Perindustrian, UU RI No. 8 tahun 1995 tentang Pasar Modal, UU RI No. 5 tahun 1997 tentang Psikotropika, UU RI No. 22 tahun 1997 tentang Narkotika, UU RI No. 32 tahun 2009 tentang Perlindungan dan Pengelolaan, UU RI No. 5 tahun 1999 tentang Larangan Praktek Monopoli dan Persaingan Usaha Tidak Sehat, UU RI No. 8 tahun 1999 tentang Perlindungan Konsumen, dan UU RI No. 20 tahun 2001 tentang Pemberantasan Tindak Pidana Korupsi. Juga dikenal dalam dua undang-undang yang sudah direvisi dan dibatalkan oleh Mahkamah Konstitusi, yakni

\footnotetext{
${ }^{21}$ Ibid, hal. 3

22 Mardjono Reksodiputro, Tindak Pidana Korporasi Dan Pertanggungjawabannya, Perubahan Wajah Pelaku Kejahatan di Indonesia, http://mahupiki.com/ demo/images/Artikel/Jogya23-27februari2014/ Tindak_Pidana_Korporasi, olehProf.Mardjono. hal. 2
} 
UU RI No. 22 tahun 2001 tentang Minyak dan Gas Bumi dan UU RI No. 20 tahun 2002 tentang Ketenagalistrikan. Namun demikian banyak yang memasukkan "korporasi" sebagai subyek tindak pidana, tetapi dengan berbagai variasi istilah, ada korporasi yang dijadikan subyek tindak pidana, tetapi undang-undang yang bersangkutan tidak membuat ketentuan pidana atau "pertanggungjawaban pidana" untuk korporasi. Dalam hal Undang-Undang membuat pertanggungjawaban korporasi, belum ada pola aturan pemidanaan korporasi yang seragam dan konsisten, seperti kapan korporasi dipertanggungjawabkan kejahatannya.

2) Sesungguhnya negara asal yaitu Belanda, ketentuan dalam KUHP terkait dengan kejahatan korporasi sudah diatur sejak tahun 1950. Selanjutnya pada tahun 1976 ketentuan Pasal 51 tersebut diubah oleh Belanda sehingga ketentuan tersebut lebih tegas dengan norma "tindak pidana dapat dilakukan oleh manusia (natuurlijke personen) dan badan hukum (rechtspersonen)". Ketentuan tersebut dituangkan dalam Un-
dang-Undang Delik Ekonomi (Wet op de Economische Delicten), yang kemudian direspons oleh Indonesia pada tahun 1955 dalam Undang-Undang RI Nomor 7 Drt/tahun 1955, Tentang Tindak Pidana Ekonomi. Sementara di negara-negara penganut common law system sudah menerapkan pertanggunganjawaban pidana korporasi, sejak revolusi industri, negara-negara penganut common law system sudah menerapkan pertanggungjawababan.

\section{Saran}

1) Diperlukan perumusan pertanggungjawaban pidana korporasi dalam perundangundangan dan memasukkan "korporasi" sebagai subyek tindak pidana, dengan ketentuan pidana atau "pertanggungjawaban pidana" untuk korporasi; kapan korporasi harus mempertanggungjawabkan tindak pidana yang dilakukannya, dan jenis sanksi untuk tindak pidana korporasi.

2) Para pemakai hukum hendaknya memahami apa dan kapan korporasi dijatuhkan pidana dan pertanggungjawabannya.

\section{Daftar Pustaka}

\section{Buku Dan Artikel}

Agustinus Pohan,1988, “Korporasi sebagai Subyek dalam Hukum Pidana” (Penataran di FH Universitas Lampung);

Alvi Syahrin, Pertanggungjawaban Pidana Korporasi. http://alviprofdr.blogspot.com/ 2013/02 /pertanggungjawabanpidana-korporasi-oleh.html,

G.A.van Hamel, Inleiding tot de studie van het Nederlandsche Strafrecht, Haalem: De Erven F. Bohn; 1927

H.J. Smidt, Geschiedenis van het Wetboek van Strafrecht (dipergunakan tahun 1880 oleh Menteri Kehakiman Mdderman di Parlrmen Belanda, 1878

Ineke Warsito, Tindakan kejahatan Korporasi dan Pertanggungjawabannya, Hill \& Co, Jakarta, 1898

J.H. de Bussy, Geschiedenis van het Wetboek van Strafreht voor Nederlandsch Indie, Amsterdam:; 1918

Jan Remmelink, Hukum Pidana.Komentar atas pasal-pasal terpenting KUHP Belanda dan padanannya dalam KUHP Indonesia, Jakarta: Gramedia, 2003

J.E.Sahetapy, Konsorsium Ilmu Hukum, Yogyakarta: Liberty, 2000.

Keenan Wicaksono, "White Collar Criminality (WCC) Dalam penentuan Pertanggungjawabannya". Hinn \& Hill, Jakarta, 2009 
Mardjono Reksodiputro, Tindak Pidana Korporasi Dan Pertanggungjawabannya, Perubahan Wajah Pelaku Kejahatan di Indonesia, http://mahupiki.com/demo/images/ Artikel/Jogya23-27 februari2014/Tindak_Pidana_Korporasi, olehProf.Mardjono.

"Pertanggungjawaban Pidana Korporasi dalam Tindak Pidana Korporasi" (Seminar Nasional di FH Universitas Diponegoro); 1989

Kemajuan Pembangunan Ekonomi dan Kejahatan, Jakarta: Lembaga Kriminologi UI, 2007.

....., Bunga Rampai Permasalahan dalam Sistem Peradilan Pidana, Jakarta: Lembaga Kriminologi UI, 2007

....., Tindak Pidana Korporasi, Jakarta: Dies Natalis PTIK Tahun 2014,

Mochtar Kusumaatmadja, Fungsi Hukum Dalam Pembangunan, Bandung: Bina Cipta, 1979

Muladi dan Dwidja Priyatno, Pertanggung jawaban Korporasi dalam Hukum Pidana, Bandung: Sekolah Tinggi Hukum, 1991,

Nico Keijzer, Criminal Liability of Corporations Under the Law of the Netherlands, tidak diterbitkan, dikirim dengan e-mail 15 Juni 2013- sebagai teks makalah yang telah dipresentasikannya di Jakarta di muka forum Satgas REDD UKP4 pada tanggal 20 Mei 2013

Schaffmeister, Keijzer, Sutorius, Hukum Pidana, Editor Penerjemahan Budiyanto. 1995

Susanto, Kejahatan Korporasi, Semarang : Badan Penerbit Universitas Diponegoro dan Yusuf Shofie, 2002, Pelaku Usaha, Konsumen dan Tindak Pidana Korporasi, Jakarta: Ghalia Indonesia, 1995

Sutan Remy Sjahdeini, Pertanggungjawaban Pidana Korporasi, Jakarta: Grafiti Pers, 2006,

Eddy O.S.Hiariej (Editor), Bunga Rampai Hukum Pidana Khusus, Pena Pundi Aksara, 2006,

Yusuf Shofie, Tanggung Jawab Pidana Korporasi dalam Hukum Perlindungan Konsumen Di Indonesia, Bandung: Citra Aditya Bakti, 2011

Wayne R.LaFave\& Austin W.Scott, Jr, Criminal Law -Hornbook Series, 1972, West Publishing Co, (Laibility Without Fault: Strict Liability -Vicarious Liability -Enterprise Liability)

Utrecht, Pengantar Ilmu Hukum, Badan yang menurut hukum berwenang menjadi pendukung hak atau setiap pendukung hak yang tidak berjiwa, Jogyakarta: RadjaGrafindo, 1990, Cetakan ke 71 